\title{
Conversion of Hydrogen on alloys and inorganic compounds
}

Chorkendorff, Ib; Hinnemann, Berit; Moses, Poul Georg; Bonde, Jacob Lindner; Andersen, Michael; Nørskov, Jens Kehlet

Published in:

Electrochemical Society. Meeting Abstracts (Online)

Publication date:

2005

Document Version

Publisher's PDF, also known as Version of record

Link back to DTU Orbit

Citation (APA):

Chorkendorff, I., Hinnemann, B., Moses, P. G., Bonde, J. L., Andersen, M., \& Nørskov, J. K. (2005). Conversion of Hydrogen on alloys and inorganic compounds. Electrochemical Society. Meeting Abstracts (Online), Abstract 1599.

\section{General rights}

Copyright and moral rights for the publications made accessible in the public portal are retained by the authors and/or other copyright owners and it is a condition of accessing publications that users recognise and abide by the legal requirements associated with these rights.

- Users may download and print one copy of any publication from the public portal for the purpose of private study or research.

- You may not further distribute the material or use it for any profit-making activity or commercial gain

- You may freely distribute the URL identifying the publication in the public portal

If you believe that this document breaches copyright please contact us providing details, and we will remove access to the work immediately and investigate your claim 


\section{Conversion of hydrogen on alloys and inorganic compounds}

I. Chorkendorff, B. Hinnemann, P. G. Moses, J.

Bonde, M. Andersen \& J.K. Nørskov,

Interdisciplinary Centre for Catalysis (ICAT), Department of Physics,

Technical University of Denmark, Building 312, DK-2800 Lyngby, Denmark

The Platinum metals are the only real good materials for producing hydrogen by electrolysis and for converting it in the low temperature PEM cells. The production of platinum only amounts to some 190 ton/year [1] and can thus easily be a severe show stopper for a future hydrogen economy [2]. There is therefore a strong demand for finding new cheap and more effective materials. This naturally involves understanding the problems with current systems.

The dissociation of Hydrogen on conventional Platinum metal anode electrode on Proton Exchange membrane Fuel Cells (PEMFC) are known to be strongly inhibited by adsorption of for instance CO. This effect has been investigated in detail both on $\mathrm{Pt}$ [3] and $\mathrm{Pt} / \mathrm{Ru}$ [4] anode by using $\mathrm{CO}$ exchange experiments on commercial electrode materials. This method allows for determination of the $\mathrm{CO}$ desorption rate under operation condition and a $\mathrm{CO}$ pressure controlling the $\mathrm{CO}$ coverage. The results show that the Ligand effect, i.e. that the strength of the $\mathrm{CO}$ bonding prevails in importance over the bifunctional effect under realistic operation conditions. This despite the fact that the $\mathrm{CO}$ desorption rate on the nanoparticles constituting the anode materials on the commercial electrodes shows a substantial lower exchange rate than on a $\mathrm{Pt}(111)$ model surface [5]. The observation is explained by a confinement effect on the nanoparticles where the packing of the $\mathrm{CO}$ must be quantized. These results are used to search for new alloys by a parallel screening approach where the search for catalyst that are good at dissociating hydrogen in the presence of $\mathrm{CO}$ and water are performed in a combined UHV-high pressure cell equipment [6].

The electrochemical hydrogen evolution process whereby protons and electrons are combined into molecular hydrogen is also catalyzed most effectively by the Pt group metals [7]. This can be understand in terms of general trends in reactivity of Hydrogen [8] and the criterion that $\Delta G_{H}^{0} \cong 0$

essential nitrogenases are also effective catalysts for the hydrogen evolution process, even though the catalytically active site of these enzymes contains the much less noble metals $\mathrm{Fe}, \mathrm{Ni}$, and $\mathrm{Mo}$, and the nitrogenase active site contains $\mathrm{S}$. Based on this criterion and especially by this biomimetic inspiration from nature has lead to investigation of $\mathrm{MoS}_{2}$ nanoparticles as a new material for hydrogen evolution [9]. Indeed, our experiments show that MoS2/graphite is a quite reasonable material for hydrogen evolution with an overpotential of the order 0.1-0.2 V. This is in excellent agreement with the predictions from theory, and it suggests that we can begin searching for new catalytic materials using quantum chemical methods. The MoS2 nanoparticles supported on graphite may be an example of a new class of electrode materials, and there are good possibilities for further optimization.

\section{References}

1.WWW.platinum.matthey.com

2. Dresselhaus, M. S., Thomas, I. L., Nature 414, 332 (2001).

3. Davies, J. C. Nielsen, R. M., Thomsen, L. B., Chorkendorff, I., Logadóttir, Á., Łodziana, Z., Nørskov, J. K., Li, W., Hammer, B., Longwitz, S. R., Schnadt, J., Vestergaard, E. K., Vang, R. T., and Besenbacher, F., Fuel Cell 4 (2004) 309319.

4. J. C. Davies, J. Bonde, Á. Logadóttir, J. K. Nørskov and I. Chorkendorff, Fuel Cell (2004) in press.

5. M. Andersen, M. Johansson, and I. Chorkendorff, submitted (2005)

6. M. Johansson, J. H. Jørgensen, and I. Chorkendorff, Rev. Sci. Instrum. 75 (2004) 2082-2093.

7. J. Bockris, A. K. Reddy, M. Gamboa-Aldeco, "Modern Electrochemistry 2A", Kluwer Academic/Plenum Publishers, New York, ed. 2, 1998.

8. J. K. Nørskov, T. Bligaard, A. Logadottir, J. R. Kitchin, J. G. Chen, S. Pandelov, and U. Stimming, J. Electrochem. Soc., in press (2004). 9. B. Hinnemann, P. G. Moses, J. Bonde, I. Chorkendorff \& J.K. Nørskov, Submitted (2004). 